Editorial

\title{
Special Issue: Microbial Degradation of Xenobiotics
}

\author{
Yuji Nagata \\ Graduate School of Life Sciences, Tohoku University, Sendai 980-8577, Japan; aynaga@ige.tohoku.ac.jp
}

Received: 20 March 2020; Accepted: 26 March 2020; Published: 30 March 2020

Xenobiotics are released into the environment by human activities, and they often cause problems such as environmental pollution, since most such compounds cannot be readily degraded, and have harmful effects on human beings and the natural ecosystem. However, some microorganisms that degrade man-made xenobiotics have been isolated. Most of these aerobic xenobiotics-degrading bacterial strains use xenobiotics as their sole source of carbon and energy, and thus they are excellent models for studying the adaptation and evolution of bacteria in the environment.

Recent genome analyses of bacterial strains that degrade xenobiotics have strongly suggested that they indeed emerged relatively recently by gathering genes for the degradation of xenobiotics, and mobile genetic elements played important roles in the recruitment of the genes [1]. However, the origin of the genes and the evolutionary processes of such bacterial strains remain largely unknown. Ongoing comprehensive genome and metagenome analyses may provide some insights into these mysteries, and the genes for the degradation of xenobiotics can be used as probes to reveal novel mechanisms for the evolution of microorganisms. In addition, enzymes for the degradation of xenobiotics are good materials for studies on protein evolution, since generally they have promiscuous activities, and their properties change dramatically with a small number of mutations [2]. On the other hand, the importance of microbial consortia and symbiosis for the degradation of xenobiotics in the environment has also been suggested [3], and thus studies on xenobiotics degradation may provide some novel concepts in the field of microbial ecology.

This issue gathers 13 articles dealing with various aspects of the microbial degradation of xenobiotics. Four of them deal with the bacterial strains that degrade monocyclic phenolic compounds [4], polylactic acid [5], and naphthalene [6], and those that accumulate perfluorohexane sulfonate [7]. Two are dedicated to bacterial consortia degrading diesel [8] and dioxane [9]. Two focus on the enzymes for degradation of haloalkanes [10] and bisphenols [11]. Three articles are related to "indirect" factors that are necessary or important for the microbial degradation of xenobiotics, i.e., transcriptional regulation [12], transporters that are involved in the transport of xenobiotic compounds across the outer membrane [13], and mobile genetic elements [14]. The last two articles address metabolic engineering [15] and the bioreactors [16] necessary for practical application.

Acknowledgments: I would like to thank all authors who contributed their excellent papers to this Special Issue. I thank the reviewers for their help in improving the papers to the highest standard of quality. I am also grateful to all members of the Microorganisms Editorial Office for giving me this opportunity, and for their continuous support in managing and organizing this Special Issue.

Conflicts of Interest: The author declares no conflict of interest.

\section{References}

1. Nagata, Y.; Kato, H.; Ohtsubo, Y.; Tsuda, M. Lessons from the genomes of lindane-degrading sphingomonads. Environ. Microbiol. Rep. 2019, 11, 630-644. [CrossRef] [PubMed]

2. Nagata, Y.; Ohtsubo, Y.; Tsuda, M. Properties and biotechnological applications of natural and engineered haloalkane dehalogenases. Appl. Microbiol. Biotechnol. 2015, 99, 9865-9881. [CrossRef] [PubMed] 
3. Ogawa, N.; Kato, H.; Kishida, K.; Ichihashi, E.; Ishige, T.; Yoshikawa, H.; Nagata, Y.; Ohtsubo, Y.; Tsuda, M. Suppression of substrate inhibition in phenanthrene-degrading Mycobacterium by co-cultivation with a non-degrading Burkholderia strain. Microbiology 2019, 165, 625-637. [CrossRef] [PubMed]

4. Mpofu, E.; Chakraborty, J.; Suzuki-Minakuchi, C.; Okada, K.; Kimura, T.; Nojiri, H. Biotransformation of Monocyclic Phenolic Compounds by Bacillus licheniformis TAB7. Microorganisms 2020, 8, 26. [CrossRef] [PubMed]

5. Decorosi, F.; Exana, M.L.; Pini, F.; Adessi, A.; Messini, A.; Giovannetti, L.; Viti, C. The Degradative Capabilities of New Amycolatopsis Isolates on Polylactic Acid. Microorganisms 2019, 7, 590. [CrossRef] [PubMed]

6. Miyazawa, D.; Thanh, L.T.H.; Tani, A.; Shintani, M.; Loc, N.H.; Hatta, T.; Kimbara, K. Isolation and Characterization of Genes Responsible for Naphthalene Degradation from Thermophilic Naphthalene Degrader, Geobacillus sp. JF8. Microorganisms 2020, 8, 44. [CrossRef] [PubMed]

7. Presentato, A.; Lampis, S.; Vantini, A.; Manea, F.; Daprà, F.; Zuccoli, S.; Vallini, G. On the Ability of Perfluorohexane Sulfonate (PFHxS) Bioaccumulation by Two Pseudomonas sp. Strains Isolated from PFAS-Contaminated Environmental Matrices. Microorganisms 2020, 8, 92. [CrossRef] [PubMed]

8. Farber, R.; Rosenberg, A.; Rozenfeld, S.; Banet, G.; Cahan, R. Bioremediation of Artificial Diesel-Contaminated Soil Using Bacterial Consortium Immobilized to Plasma-Pretreated Wood Waste. Microorganisms 2019, 7, 497. [CrossRef] [PubMed]

9. Tusher, T.R.; Shimizu, T.; Inoue, C.; Chien, M.-F. Enrichment and Analysis of Stable 1,4-dioxane-Degrading Microbial Consortia Consisting of Novel Dioxane-Degraders. Microorganisms 2020, 8, 50. [CrossRef] [PubMed]

10. Chrast, L.; Tratsiak, K.; Planas-Iglesias, J.; Daniel, L.; Prudnikova, T.; Brezovsky, J.; Bednar, D.; Kuta Smatanova, I.; Chaloupkova, R.; Damborsky, J. Deciphering the Structural Basis of High Thermostability of Dehalogenase from Psychrophilic Bacterium Marinobacter sp. ELB17. Microorganisms 2019, 7, 498. [CrossRef] [PubMed]

11. Takeo, M.; Akizuki, J.; Kawasaki, A.; Negoro, S. Degradation Potential of the Nonylphenol Monooxygenase of Sphingomonas sp. NP5 for Bisphenols and Their Structural Analogs. Microorganisms 2020, 8, 284. [CrossRef] [PubMed]

12. Gibu, N.; Kasai, D.; Ikawa, T.; Akiyama, E.; Fukuda, M. Characterization and Transcriptional Regulation of n-Alkane Hydroxylase Gene Cluster of Rhodococcus jostii RHA1. Microorganisms 2019, 7, 479. [CrossRef] [PubMed]

13. Samantarrai, D.; Lakshman Sagar, A.; Gudla, R.; Siddavattam, D. TonB-Dependent Transporters in Sphingomonads: Unraveling Their Distribution and Function in Environmental Adaptation. Microorganisms 2020, 8, 359. [CrossRef] [PubMed]

14. Chien, M.-F.; Ho, Y.-N.; Yang, H.-E.; Narita, M.; Miyauchi, K.; Endo, G.; Huang, C.-C. Identification of A Novel Arsenic Resistance Transposon Nested in A Mercury Resistance Transposon of Bacillus sp. MB24. Microorganisms 2019, 7, 566. [CrossRef] [PubMed]

15. Demko, M.; Chrást, L.; Dvořák, P.; Damborský, J.; Šafránek, D. Computational Modelling of Metabolic Burden and Substrate Toxicity in Escherichia coli Carrying a Synthetic Metabolic Pathway. Microorganisms 2019, 7, 553. [CrossRef]

16. Miyoshi, Y.; Okada, J.; Urata, T.; Shintani, M.; Kimbara, K. A Rotational Slurry Bioreactor Accelerates Biodegradation of A-Fuel in Oil-Contaminated Soil Even under Low Temperature Conditions. Microorganisms 2020, 8, 291. [CrossRef] [PubMed]

(C) 2020 by the author. Licensee MDPI, Basel, Switzerland. This article is an open access article distributed under the terms and conditions of the Creative Commons Attribution (CC BY) license (http://creativecommons.org/licenses/by/4.0/). 